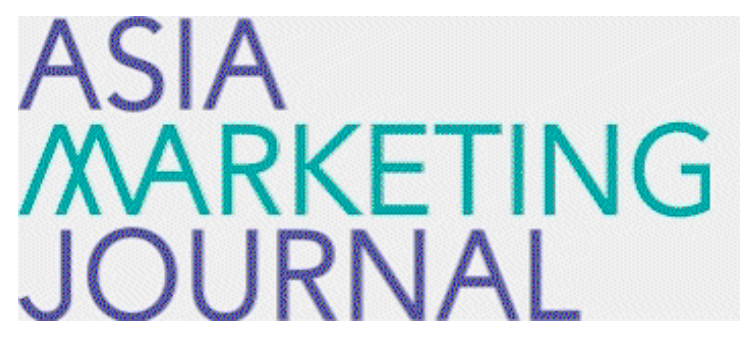

ASIA MARKETING JOURNAL

Volume 8 | Issue 1

Article 2

$4-25-2006$

\title{
편집위원장 임기를 마치며
}

인수 전

Follow this and additional works at: https://amj.kma.re.kr/journal

Part of the Marketing Commons

\section{Recommended Citation}

전, 인 수 (2006) "편집위원 장 입기를 마치며," Asia Marketing Journal: Vol. 8 : Iss. 1 , Article 2.

Available at: https://doi.org/10.53728/2765-6500.1160

This Article is brought to you for free and open access by Asia Marketing Journal. It has been accepted for inclusion in Asia Marketing Journal by an authorized editor of Asia Marketing Journal. 


\section{편집위원장 임기를 마치며}

한국마케팅저널은 주지하다시피 마케팅연구와 함께 한국마케팅학회에서 발간하는 두 학회지 중 하 나입니다. 1999년 3월에 시작하였으니 7년이 넘어 2006년 현재 8년차에 접어들고 있는 성장기에 있 는 학회지입니다. 그 동안 초대 편집위원장이신 김재일(서울대) 교수님을 비롯한 예종석(한양대), 최 낙환(전북대) 교수님에 이어 제가 4대 편집위원장으로 2004년 4월부터 소임을 시작하여 2006년 3월 21일에 업무를 인계하였습니다. 앞선 위원장님들의 노고에 힘 얻어 이제야 부끄럽지 않는 학회지로 자리매김 한 것 같아 감개가 무량하며 훌륭한 학자이신 후임 편집위원장님께 바톤을 넘기게 된 것에 감사할 따름입니다.

한국마케팅저널이 이 만큼이나 자리를 잡게 된 것은 저의 능력보다는 전적으로 학회회원님들의 헙 조와 격려 덕분임을 밝힙니다. 특히 까다로운 심사과정을 감내하면서 논문을 투고하여 주신 저자들 께 먼저 감사를 드립니다. 게재불가를 통보하는 저의 마음도 아팠으니 좋지 않은 결과를 접한 저자 들의 심정이야 오죽하겠습니까마는 한 분도 이의를 제기하지 않으시고 결과에 승복해 주신 점 다시 한번 머리 숙여 감사드립니다. 또한 편집위원들을 비롯한 심사위원들께도 심심한 사의를 표합니다. 김영찬(연세대), 박성연(이화여대), 박찬수(고려대), 서찬주(숙명여대), 오창호(한신대), 이의훈(한국 정보통신대) 교수님들 고맙고 또 고맙습니다. 특히 전자저널이라 모두 인터넷으로 심사가 이루어져 무척 귀찮았을 텐데도 아무 말씀 안하시고 저의 독촉을 받아주신 심사위원님들께 머리 숙여 감사드 립니다. 메일로 독촉을 하고 조교시켜 전화도 하게 하였지요? 송구합니다.

회원님들과 이런 분들 덕분에 학진등재지 1차 심사는 통과하였고 올해 2 차 심사를 받으면 등재지 가 됩니다. 1차 심사는 2004년에 발간된 학회지로, 2차 심사는 2005년에 발간된 학회지로 심사를 받 는데 2005년에 더 개선되었으니 2차 통과(약 90점 정도가 될 것임)는 거의 확실하여 심사결과가 공 포되는 2006년말이면 한국마케팅학회는 두 개의 등재학회지를 갖게 됩니다. 무척 자랑스러운 일입니 다. 이는 학회운영을 맡아 고생하신 역대 회장님들의 노고가 밑바탕이 된 것으로 보아야 할 것입니다. 재임기간 동안 등재지가 되는 것에 목표를 두었기 때문에 학회지가 어떻게 개선되었는 지에 대한 소상한 지표는 말씀드리지 않겠습니다. 다만 제가 편집위원장을 맡으면서 느낀 점 몇 가지만 정리하 고 임기를 마무리 합니다.

첫째, 없는 살림하기가 참 힘들다는 것입니다. 심사는 제 때 이루어지지 않고 발간 날자는 다가오 고 적정 편수(5편 정도)를 채우지 못하면 정말 피가 마릅니다. 제가 없는 살림이라 표현한 것은 마 케팅연구에 비해 양적, 질적 차이가 난다는 것입니다. 따라서 조교에게 맡겨둘 수가 없어 모든 것을 제 손으로 했습니다. 1 주일에 5 시간 정도는 완전히 심사 및 편집일에 투자한 듯합니다. 워낙 제가 모든 일을 하다보니 교통사고라도 나면 안 될 것 같아 운전을 조심한 덕분에 운전 버룻은 좋아졌 습니다. 
둘째, 편집규정이나 투고요령을 무시하고 보내는 논문들이 많아 수정하고 편집하는데 애를 먹었습 니다. 물론 일일이 다 맞추기는 어렵지만 조금만 더 신경을 쓰시면 될 것 같아 가장 문제가 많다고 생각되는 한 가지만 짚고 넘어가려 합니다. 참고문헌입니다. 우선 너무 많고 인용하는 형식이나 참고 문헌을 정리하는 방식이 투고요령에 일치하지 않는 경우가 흔합니다. 외람된 제안이지만 한국마케팅 저널에 실리는 논문의 참고문헌은 2-3페이지를 넘기지 말았으면 좋겠다고 생각합니다. 꼭 읽어보고 key articles만 참고문헌에 넣어주면 차후 연구에 도움도 되고 모양도 더 좋아 보일 것으로 사료됩니다.

셋째, 논문의 요약, abstract, 그리고 keyword입니다. 이들은 모두 논문의 독자를 위한 서비스인데 너무 간단하거나 성의가 없어 형식에 불과하다는 생각이 드는 경우가 종종 있습니다. 정확히 논문의 핵심내용을 요약해야 하겠지만 분량도 어느 정도는 돼야 하는데 2-3줄에 끝내는 경우가 흔합니다. 편집 시에 abstract를 위해 한 페이지를 할애한다는 점을 미리 생각하시어 분량을 조절하심이 좋을 듯 합니다. 특히 keyword는 심각합니다. 논문을 다 읽지 않고서도 해당 논문이 어느 분야에 속하는 지 어떤 점을 새로 연구했는지 알 수 있게 하는 것이 keyword의 역할입니다.

끝으로, 한국마케팅저널은 창의성을 존중한다는 본래의 취지를 살리기가 너무 힘듭니다. 무엇을 창 의성으로 보아야 할 지부터 애매하고 또 나름대로의 기준을 정하더라도 기준을 통과하는 논문의 수 가 많지 않습니다. 따라서 투고자들이 Journal of Marketing에 가까운 논문이라고 생각하고 제출하여 주기를 바랄 뿐이고 심사자들 또한 그렇게 알고 심사해야 하는데 그것이 좀체 잘 되지 않습니다. 한 학회에서 발간되는 두 학회지의 성격규정은 앞으로 해결해야 할 과제로 남겨둡니다. 다만 Second Journal이 아니라 Another Journal로 존중받기를 바랍니다.

손을 놓는다고 생각하니 섭섭함 보다는 너무 좋습니다. 전혀 아쉬운 점이 없을 정도로 나름의 최 선을 다했습니다. 부족한 점이 있었다면 그것은 전적으로 저의 능력 부족으로 보아주시기 바랍니다. 모쪼록 저로 인해 섭섭한 마음이 있으신 분들은 용서하시고 웃는 얼굴로 학회에서 ㅂyㅂ도록 하지요. 쇼트트랙 $3000 \mathrm{~m}$ 결승에서 변천사가 뒤에서 치고 나와 진선유의 엉덩이를 힘껏 밀어주어 결승선에 맨 먼저 스케이트 날을 들이 미는 모습이 너무 아름다웠습니다. 저의 모든 정성을 모아 후임 편집위 원장이신 한상만 교수님의 뒤를 힘껏 밉니다.

2006년 3월 31일

한국마케팅저널 4대 편집위원장 홍익대학교 교수 전 인 수 드림 